\title{
Feeding practices for wild pigs to develop pork processing as value addition in northern region of Vietnam
}

\author{
B.T. Thom ${ }^{1}$, D.T.N. Huy ${ }^{2 *}$, B.T. Suu ${ }^{3}$, N.T. Hoa ${ }^{4}$, D.T. Hien ${ }^{5}$
}

${ }^{1}$ Thai Nguyen University of Agriculture and Forestry; ${ }^{2}$ Banking University HCMC, Ho Chi Minh city; ${ }^{3}$ Tay Bac University, Quyet Tam Ward, Son La City, Son La Province; ${ }^{4}$ Thu Dau Mot University, Binh Duong, ${ }^{5}$ Thai Nguyen University of Sciences, Thai Nguyen Vietnam

*Corresponding author e-mail- $\underline{\text { dtnhuy2010@gmail.com }}$

Journal of Livestock Science (ISSN online 2277-6214) 12: 303-311

Received on 18/8/21; Accepted on 5/10/21; Published on 20/10/21

doi. 10.33259/JLivestSci.2021.303-311

\begin{abstract}
It is the time we need to explore livestock value chain in wild pigs and wild pork in the Northern region of Vietnam. Thom, B.T., \&Huy, D.T.N (2021) stated At present, most pig breeds are selected and raised in accordance with local conditions, especially wild boar and hybrids are very popular with people, the demand for products is increasing day by day. In this paper, the research team selected a selective sampling survey method with a non-random manner with the determination of the sample size in accordance with the data analysis method. It used qualitative analysis with synthesis, inductive methods, references and experience from experts. The results showed that for commercial wild boar farming, the diet has a protein level of 16-14\% and a metabolic energy level of 3000-2900 kcal $/ \mathrm{kg}$ of feed in the diet for growth and fattening stages respectively is the most reasonable, both capable of growth of hybrid wild boar and economically viable in breeding conditions by semi-wild method in ecological conditions of Thai Nguyen. Beside, in recent years, under covid 19 effects, the concept of cycled economy is important to maintain high rate of employment and help the economic growth. Therefore, every stages in wild pigs and pork cycle from input to production and distribution to market need to be in a cycle and can be supported by big corporations.
\end{abstract}

Key words: wild pigs; pork; cycled economic value chain; livestock sector; Northern region; Vietnam 


\section{Introduction}

Pig farming is very important in Vietnam, especially in Thai Nguyen city and Northern provinces (Thom et al 2021). Pork products are suitable for people's taste. The results of several studies in this regard are summarized a below,

Table 1 - Summary of previous studies

\begin{tabular}{|l|l|}
\hline Authors & Contents, results \\
\hline $\begin{array}{l}\text { Simons et } \\
\text { al } 2008\end{array}$ & $\begin{array}{l}\text { Value Chain Analysis (VCA) is a tool for analysing the nature and source of value within a } \\
\text { supply chain and the potential for reducing waste therein, with the focus explicitly on the } \\
\text { determinants of value within a manufacturing process rather than the simple measurement of } \\
\text { process outputs. The tool has been successfully applied in recent years within the motor and } \\
\text { information technology industries, to assist forward thinking businesses to survive in an } \\
\text { increasingly competitive environment. }\end{array}$ \\
\hline $\begin{array}{l}\text { Thom \& } \\
\text { Huy, 2021 }\end{array}$ & $\begin{array}{l}\text { Feeding wild pigs and managing wild pork meat quality is meaningful in Vietnam, esp. In } \\
\text { Thai Nguyen province as pork products can offer variety of tastes due to food processing and } \\
\text { suitable for Vietnamese tastes and can export to the world widely }\end{array}$ \\
\hline $\begin{array}{l}\text { Ehlers and } \\
\text { Anders } \\
2017\end{array}$ & $\begin{array}{l}\text { checked the state of pork supply as to its neglect of developing innovations and mechanisms } \\
\text { for delivering superior eating quality to consumers. We explore reasons behind pork supply } \\
\text { chains' predominant focus on mass production combined with traceability and food safety }\end{array}$ \\
\hline $\begin{array}{l}\text { Yuzaria et } \\
\text { al 2020 }\end{array}$ & $\begin{array}{l}\text { the value chains involved in i-Ternak as a website manager are investors, suppliers, breeders } \\
\text { and processors and distributors of cattle and meat. The margin obtained is still low as investors } \\
\text { get 7.76\% per 6 months, the biggest chain with margins is meat processed while the lowest is } \\
\text { livestock. }\end{array}$ \\
\hline $\begin{array}{l}\text { Thom et al } \\
2021\end{array}$ & $\begin{array}{l}\text { For commercial cross-bred wild boar farming, a diet with a protein level of 16-14\% and a } \\
\text { metabolic energy level of 3000-2900 kcal/kg of feed in the diet for growth and fattening most } \\
\text { appropriate }\end{array}$ \\
\hline
\end{tabular}

Djanza et al (2013) mentioned beef value chain in Malawi as follows:

Figure 1- Beef value chain from farm-gate to distribution

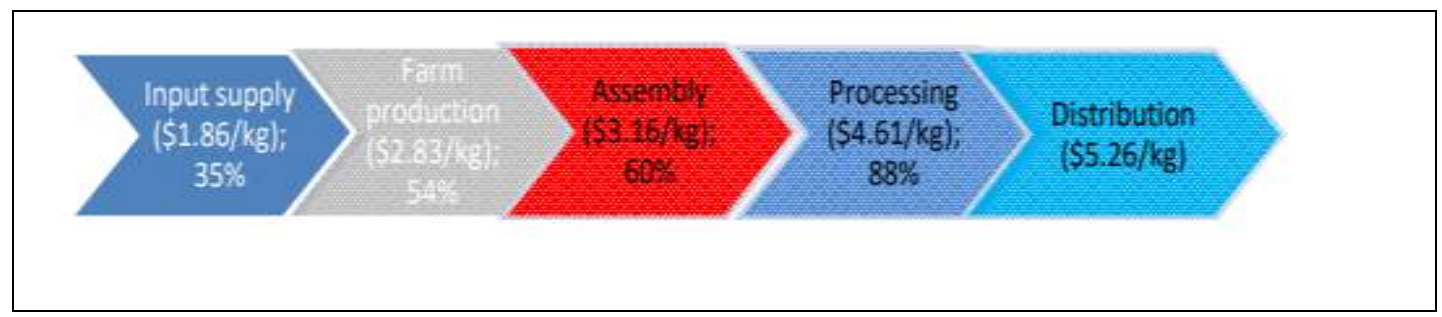

In a long time, value chain analysis became an effective tool in many industries including livestock sector, that's why in this study scope of wild pigs we come back to value chain concept to enhance value for Vietnam livestock sector.

The present study was taken up to provide data on appropriate crude protein and energy levels for F2 wild boars; to generate research materials on nutritional feed for pigs; to develop supplementary materials in teaching and studying students, training for breeders, contributing to the development of hybrid wild boar breeding in the Northern area of Vietnam. It was aimed to provide answer to following questions,

(i) What are factors affecting nutrition food mechanism for wild board?

(ii) What factors affecting pork meat quality?

(iii) What are value chain concepts in wild pigs and pork? 


\section{Methodology}

\section{Method and Data}

The research team selected a selective sampling survey method with a non-random manner with the determination of the sample size in accordance with the data analysis method. This study also used Experimental set-up method, under references and experience from experts. Author also use qualitative analysis with synthesis, inductive methods. Duration of study was approximately 8 months.

These wild pigs are fed in Thai Nguyen Farms. The meat was analyzed for crude protein, crude lipids, total minerals, dry matter, $\mathrm{pH}$ value, $\mathrm{pH} 45$ minutes after slaughter, toughness, color and blood collection to check the content of Cholesterol, Triglyceride on BT 1500 device and automatic counter of the Hospital of Thai Nguyen University of Medicine and Pharmacy. The method of determining the quality of feed, the quality of experimental pork is calculated on the equipment system of the Institute of Life Sciences, Thai Nguyen University based on Vietnamese standards.

The cost of feed / $\mathrm{kg}$ of weight gain was analysed as Feed cost $/ 1 \mathrm{~kg}$ increase in volume $(\mathrm{VND})=$ Feed consumed $(\mathrm{kg})$ cost of $1 \mathrm{~kg}$ of feed $(\mathrm{VND}) / \sum$ weight gain in the experiment period $(\mathrm{kg})$

Table 2 - Feed consumption/day of experimental pigs (kg/head/day)

\begin{tabular}{|l|l|l|l|l|l|l|}
\hline \multirow{2}{*}{$\begin{array}{l}\text { Stages of } \\
\text { experiment }\end{array}$} & \multicolumn{2}{|c|}{ Lot TN1 } & \multicolumn{3}{c|}{ Lot TN2 } & \multicolumn{2}{c|}{ Lot TN3 } \\
\cline { 2 - 7 } Core food & Green food & Core food & Green food & Core food & Green food \\
\hline Begin -1 month & 0.25 & 0.51 & 0.21 & 0.49 & 0.19 & 0.46 \\
\hline 02-Month1 & 0.37 & 0.79 & 0.39 & 0.75 & 0.35 & 0.71 \\
\hline 03-Month 2 & 0.53 & 1.22 & 0.55 & 1.20 & 0.52 & 1.18 \\
\hline 04-Month 3 & 0.65 & 1.44 & 0.61 & 1.51 & 0.66 & 1.43 \\
\hline Average stage 1 & 0.45 & 0.99 & 0.44 & 0.99 & 0.43 & 0.95 \\
\hline Compare (\%) & 100 & 100 & 97.78 & 100 & 95.56 & 95.45 \\
\hline 05-Month 4 & 0.76 & 1.73 & 0.73 & 1.72 & 0.80 & 1.80 \\
\hline 06-Month 5 & 0.95 & 2.10 & 0.92 & 2.00 & 1.11 & 2.25 \\
\hline 07-Month 6 & 1.11 & 2.45 & 1.04 & 2.55 & 1.07 & 2.56 \\
\hline 08-Month 7 & 1.21 & 2.99 & 1.23 & 2.79 & 1.22 & 3.04 \\
\hline Average stage 2 & 1.01 & 2.32 & 0.98 & 2.27 & 1.05 & 2.41 \\
\hline Compare (\%) & 100 & 100 & 97.27 & 97.73 & 104.22 & 104.10 \\
\hline Overall mean & 0.73 & 1.65 & 0.71 & 1.63 & 0.74 & 1.68 \\
\hline Compare (\%) & 100 & 100 & 97.43 & 98.34 & 101.54 & 101.51 \\
\hline
\end{tabular}

(source: Thai Nguyen University of Agriculture and Forestry,Wild pigs project, Bui Thi Thom, 2013)

The cost of feeding wild pigs was as below:

Cost to buy breeding stock wild boar: $500 \mathrm{~m}$ VND

Cost of building barn: $200 \mathrm{~m}$ VND

Feed cost: including feed for wild boar parents and piglets born from broodstock: $225 \mathrm{~m}$ VND

Electricity and water costs: $15 \mathrm{~m} \mathrm{VND/year}$

Labor cost (2 people): $100 \mathrm{~m}$ VND

Total cost in 1 year $=10,000,000($ barn $)+225,000,000($ food $)+15,000,000($ electricity, water $)+$ $100,000,000$ (labor) $=350,000,000$ VND.

(source: https://nongnghiep.farmvina.com/nuoi-lon-rung/\#BN-1f901905cb5a0599, access date 10/9/2021).

The sale price of products was as below:

Type 1: 180,000 VND/1kg steam.

Type F2: 170,000 VND / $1 \mathrm{~kg}$ of steam.

Commercial wild boar type 1: One pore with 3 pores, stiff hair, $1 \mathrm{~cm}$ thick inner skin, little fat.

Commercial wild boar type 2: 1 hole 3 pores, soft hair, $0.5 \mathrm{~cm}$ thick opaque skin, little fat.

(source: TNC wild pig farm. https://www.lonrung.com/gia-lon-rung,acces date 10/9/2021). 


\section{Results}

We recognize that (see table 3) the main food material with highest ratio include Red kemel, bran and soybean meal. And total protein contains highest in food .

\section{Feeding wild pigs}

Table 3- Experimental diet of wild boar F2 (first time) (Growth stage)

\begin{tabular}{|c|c|c|c|c|c|c|c|}
\hline \multirow[t]{2}{*}{ Food material } & \multirow{2}{*}{$\begin{array}{l}\text { Food price } \\
/ \mathrm{kg}\end{array}$} & \multicolumn{2}{|c|}{ Lot TN $1(17 \%)$} & \multicolumn{2}{|c|}{ Lot TN $2(16 \%)$} & \multicolumn{2}{|c|}{ Lot TN $3(15 \%)$} \\
\hline & & Ratio (\%) & Value (VND) & Ratio (\%) & Value (VND) & Ratio (\%) & Value (VND) \\
\hline Red kernel corn & 7,200 & 55.00 & 3,960 & 56.00 & 4,032 & 53.00 & 3,816 \\
\hline Bran & 8,000 & 20.00 & 1,600 & 21.00 & 1,680 & 24.00 & 1,920 \\
\hline Soybean meal & 16,200 & 18.00 & 2,916 & 16.00 & 2,592 & 15.50 & 2,511 \\
\hline Fish meal grade I & 23,000 & 3 & 690 & 3 & 690 & 3 & 690 \\
\hline Vegetable oil & 12,500 & 3 & 375 & 3 & 375 & 3 & 375 \\
\hline Salt & 2,000 & 0.14 & 3 & 0.14 & 3 & 0.14 & 3 \\
\hline Lime & 600 & 1.13 & 7 & 1.13 & 7 & 1.13 & 7 \\
\hline $\begin{array}{l}\text { Green food (elephant } \\
\text { grass, banana stem) }\end{array}$ & 500 & & Free eat & & Free eat & & Free eat \\
\hline \multicolumn{2}{|l|}{ Total } & 100 & 9,551 & 100 & 9,379 & 100 & 9,322 \\
\hline \multicolumn{8}{|l|}{$1 \mathrm{~kg}$ food has } \\
\hline \multicolumn{2}{|l|}{ Metabolic energy(Kcal) } & \multicolumn{6}{|l|}{3000} \\
\hline \multicolumn{2}{|l|}{ Total Protein (gam) } & 170 & & 160 & & 150 & \\
\hline \multicolumn{2}{|l|}{ Canxi (gam) } & 10 & & 10 & & 10 & \\
\hline \multicolumn{2}{|l|}{ Photpho (gam) } & 8 & & 8 & & 8 & \\
\hline
\end{tabular}

(source: Thai Nguyen University of Agriculture and Forestry,Wild pigs project, Bui Thi Thom, 2013)

Table 4- Experimental diet of wild boar F2 (first time) (fattening phase)

\begin{tabular}{|c|c|c|c|c|c|c|c|}
\hline \multirow[t]{2}{*}{ Food material } & \multirow{2}{*}{$\begin{array}{l}\text { Food price } \\
/ \mathrm{kg}\end{array}$} & \multicolumn{2}{|l|}{ Lot TN 1} & \multicolumn{2}{|l|}{ Lot TN 2} & \multicolumn{2}{|l|}{ Lot TN 3} \\
\hline & & Ratio (\%) & Value (VND) & Ratio $(\%)$ & Value (VND) & Ratio (\%) & Value (VND) \\
\hline Red kernel corn & 7,200 & 57 & 4,104 & 56 & 4,032 & 52 & 3,744 \\
\hline Bran & 8,000 & 22 & 1,760 & 19 & 1,520 & 27 & 2,160 \\
\hline Soybean meal & 16,200 & 12.74 & 2,064 & 12.4 & 2,009 & 12.32 & 1,996 \\
\hline Fish meal grade I & 23,000 & 2.03 & 467 & 2.2 & 506 & 1.95 & 449 \\
\hline Vegetable oil & 12,500 & 5 & 625 & 5 & 625 & 5 & 625 \\
\hline Salt & 2,000 & 0.2 & 4 & 0.14 & 3 & 0.14 & 3 \\
\hline Lime & 600 & 1.03 & 6 & 1.06 & 6 & 1.09 & 7 \\
\hline $\begin{array}{l}\text { Green food (elephant } \\
\text { grass, banana stem) }\end{array}$ & 500 & & Free eat & & Free eat & & Free eat \\
\hline \multicolumn{2}{|l|}{ Total } & 100 & 9,030 & 96 & 8,701 & 100 & 8,983 \\
\hline \multicolumn{8}{|l|}{$1 \mathrm{~kg}$ food has } \\
\hline \multicolumn{2}{|l|}{ Metabolic energy(Kcal) } & \multicolumn{6}{|l|}{3000} \\
\hline \multicolumn{2}{|c|}{ Total Protein (gam) } & 150 & & 140 & & 130 & \\
\hline \multicolumn{2}{|l|}{ Canxi (gam) } & 10 & & 10 & & 10 & \\
\hline \multicolumn{2}{|l|}{ Photpho (gam) } & 8 & & 8 & & 8 & \\
\hline
\end{tabular}

(source: Thai Nguyen University of Agriculture and Forestry, Wild pigs project, Bui Thi Thom, 2013) 
Thom et al 2021/ J. Livestock Sci. 12: 303-311

Table 5-. Ingredients of experimental feed for F2 .hybrid wild boar (Growth stage) (2nd time)

\begin{tabular}{|c|c|c|c|c|c|}
\hline \multirow[t]{2}{*}{ Food material } & \multirow{2}{*}{$\begin{array}{l}\text { Food price } \\
/ \mathrm{kg}\end{array}$} & \multicolumn{2}{|l|}{ Lot TN 1} & \multicolumn{2}{|l|}{ Lot TN 2} \\
\hline & & Ratio (\%) & Value (VND) & Ratio (\%) & Value (VND) \\
\hline Red kernel corn & 7.500 & 57.00 & 4.275 & 57.00 & 4.275 \\
\hline Bran & 7.200 & 23.21 & 1.671 & 24.20 & 1.742 \\
\hline Soybean meal & 16.500 & 13.20 & 2.178 & 12.23 & 2.018 \\
\hline Fish meal grade I & 23.000 & 2.5 & 575 & 2.5 & 575 \\
\hline Vegetable oil & 12.500 & 2.8 & 350 & 2.8 & 350 \\
\hline Salt & 2.000 & 0.15 & 3 & 0.14 & 3 \\
\hline Lime & 500 & 1.14 & 6 & 1.13 & 6 \\
\hline $\begin{array}{l}\text { Green food (elephant } \\
\text { grass, banana stem) }\end{array}$ & 1.000 & & Free eat & & Free eat \\
\hline \multicolumn{2}{|l|}{ Total } & 100.00 & 9.057 .82 & 100.00 & 8.968 .80 \\
\hline \multicolumn{6}{|l|}{$1 \mathrm{~kg}$ food has } \\
\hline \multicolumn{2}{|l|}{ Metabolic energy (Kcal) } & \multicolumn{2}{|l|}{3000} & \multicolumn{2}{|l|}{2900} \\
\hline Total Protein (gam) & & 160 & & 160 & \\
\hline Canxi (gam) & & 10 & & 10 & \\
\hline Photpho (gam) & & 8 & & 8 & \\
\hline
\end{tabular}

(source: Thai Nguyen University of Agriculture and Forestry,Wild pigs project, Bui Thi Thom, 2013)

Hence, we see that bran and soybean meal covered with higher ratio (in table 5) compared to their ratio (in table 4). Effect of nutritional composition in the diet: Dietary composition from a modern point of view is the general balance in terms of quantity and quality of nutrients such as protein, amino acids, minerals, vitamins, and starch. flour, fat with an appropriate ratio to ensure high digestibility and feed efficiency, in which the appropriate protein ratio will contribute to feed costs, reduce costs and improve productivity. In the balance relationships between nutritional components, people are most often interested in the protein/Exchange energy (energy) relationship; amino acids/energy, maximum fiber content. The nutritional balance in the diet was developed for pig subjects and incorporated into the dietary standards.

A regular problem is that in the adult body, there is generally no accumulation of protein, but only the renewal of protein according to the principle of keeping nitrogen balance. But in growing pigs, if the diet only provides enough protein for maintenance, increasing the percentage of dietary protein will lead to an increase in protein digestibility to establish a positive nitrogen balance at a gradually higher level. However, when the protein supply is too high compared to the accumulated demand (protein excess), the amount of nitrogen excreted will increase and the nitrogen balance is established at a high level, conversely, when the amount of protein decreases, it is lower than that with the need for protein accumulation, the nitrogen balance is again established at a lower level. From that, it can be seen that, in the condition that the diet meets sufficient protein quality, the arrangement of diets with reduced protein levels inevitably leads to an increase in the digestibility and utilization efficiency of dietary protein and a decrease in nitrogen content discharged. On the contrary, a diet with a high percentage of protein, not only reduces the rate of digestion and absorption of protein, but also increases the burden on the digestive organs, liver, and kidneys, and also wastes protein as well as increases pollution.

Not only the protein level, but the energy/protein or energy/amino acid relationship in the diet also affects the animal's feed utilization. This relationship is expressed in grams of protein or, more specifically, as grams of amino acids/1000 Kcal ME. These nutritional relationships have also been standardized to ensure the energy requirements for protein synthesis and storage in lean meat. If there is a lack of energy, it will lead to the body having to mobilize protein for energy, causing unnecessary waste.

One of the effects of nutritional composition on the digestibility of protein and amino acids in the diet is the balance between amino acids in the ingested protein. If the feed has a reasonable ratio between amino acids, it will reduce the protein requirements of pigs. Diets containing adequate and balanced essential amino acids, suitable to the needs of growing pigs at each growth stage, will be the basis of a reasonable reduction in total protein in the diet in order to save money and save protein food. 


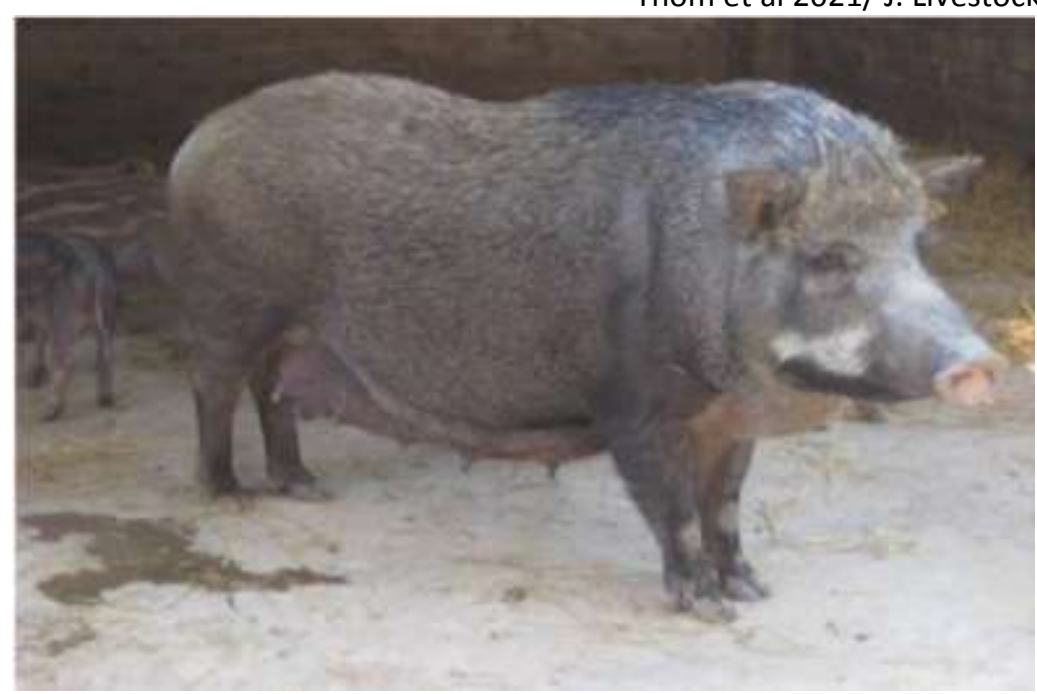

Figure 1 - Wild pigs in Vietnam (source: internet)

Survey results on yield and quality of experimental pork

Survey results

The survey at the end of the experiment is an important indicator of meat quality and whether it meets consumer demand or not.

Table 6- Results of slaughtering and yielding experimental pork

\begin{tabular}{|l|l|l|l|l|}
\hline \multirow{2}{*}{ No. } & \multirow{2}{*}{ Describe } & Lot TN1 & Lot TN2 & Lot TN 3 \\
\cline { 3 - 5 } & & $\overline{\mathrm{X}}_{ \pm \mathrm{m}} \overline{\mathrm{x}}$ & $\overline{\mathrm{X}}_{ \pm \mathrm{m}} \overline{\mathrm{x}}$ & $\overline{\mathrm{X}}_{ \pm \mathrm{m}} \overline{\mathrm{x}}$ \\
\hline 1 & Live weight (kg) & $31.00 \pm 2.45$ & $31.50 \pm 2.16$ & $30.20 \pm 1.98$ \\
\hline 2 & Meat cut quantity(kg) & $21.26 \pm 2.10$ & $21.62 \pm 2.15$ & $20.61 \pm 2.78$ \\
\hline 3 & Hook rate (\%) & $78.42 \pm 0.19$ & $78.85 \pm 0.43$ & $78.51 \pm 0.78$ \\
\hline 4 & Carcass percentage (\%) & $68.57 \pm 1.26$ & $68.65 \pm 2.09$ & $68.25 \pm 2.12$ \\
\hline 5 & Lean meat percentage (\%) & $56.85 \mathrm{a} \pm 0.81$ & $55.65 \mathrm{a} \pm 1.11$ & $54.89 \mathrm{a} \pm 0.98$ \\
\hline 6 & Fat percentage (\%) & $14.06 \pm 0.76$ & $14.36 \pm 0.45$ & $14.69 \pm 1.05$ \\
\hline
\end{tabular}

(source: Thai Nguyen University of Agriculture and Forestry,Wild pigs project, Thom, 2013)

The survey results are presented in Table 6, showing that: The percentage of carcass meat in 3 experimental groups did not differ significantly $(68.57-68.65-68.25 \%)$. For meat pigs, the percentage of lean meat is the most important and valuable criterion in carcass carcasses. The higher the percentage of lean meat, the higher the quality of the carcass, and the higher the selling price of pork. Among the 3 experimental groups, the lean percentage was highest in TN1 group (56.85\%), TN2 and TN3 groups were $55.65 \%$ and $54.89 \%$, respectively. However, the results of Table 4.7 show that in the experimental groups, with the same results of the experimental pigs, the lean percentage in the experimental groups with a high percentage of protein has a higher percentage of lean meat. but the percentage of fat tends to increase. However, the difference was not significant, not statistically significant $(\mathrm{P}>0.05)$. In this experiment, the lean percentage was higher than that of Nguyen Ngoc Phuc et al. (2010) at 43.36 (Khua Pig) and 47.36\% F1 crossbreed (Wild Boar x Khua). Meanwhile, the Tapa pig in Cao Bang is 32.9\% (Trung et al. (2010); Soc pig in Quang Tri, the lean percentage is $43.2 \%$.

The percentage of fat in the experimental plots reached from 14.06 to $14.69 \%$, the lowest in TN1 $(14.06 \%)$ and the highest in TN3 (14.69\%). Comparing the study of Phuc et al. (2010) in Khua pigs and F1 hybrids (wild boars $x$ Khua) at the end of the growth period at $21.62 \%-17.07 \%$, respectively. our experiment lower fat percentage. The experimental results of F2 hybrid wild boar had the same proportion of carcass and jaw hook as that of Muong Khuong pig (the ratio of jaw hooking was 73.50-78.62\%, the carcass rate was $64.08-69.83)$. \%) but the percentage of lean meat was higher than that of the brackish Muong Khuong (39.89-46.41\%) when slaughtered at 10 months of age (Le Dinh Cuong (2008). 
Thom et al 2021/ J. Livestock Sci. 12: 303-311

The above analysis shows that increasing and decreasing the amount of protein in the diet has an effect on the percentage of lean and fat in the experimental groups. This is the initial basis for building a reasonable diet for F2 hybrid wild boar.

Results of evaluating the quality of experimental pork

In addition, the experiment also assessed meat quality through a number of criteria presented in Table 7.

Table 7- Results of evaluating the quality of experimental pork

\begin{tabular}{|l|l|l|l|}
\hline \multirow{2}{*}{ Describe } & Lot TN1 & Lot TN2 & Lot TN3 \\
\cline { 2 - 4 } & $\overline{\mathrm{X}}_{ \pm \mathrm{m}} \overline{\mathrm{x}}$ & $\overline{\mathrm{X}}_{ \pm \mathrm{m}} \overline{\mathrm{x}}$ & $\overline{\mathrm{X}}_{ \pm \mathrm{m}} \overline{\mathrm{x}}$ \\
\hline Meat color after cut(Minolta L*) (brightness) & $48.02 \pm 1.11$ & $47.95 \pm 1.54$ & $47.83 \pm 1.36$ \\
\hline Meat toughness (kg/ cm2) & $4.85 \pm 1.23$ & $4.89 \pm 1.56$ & $4.95 \pm 1.25$ \\
\hline $\mathrm{pH}$ of tenderloin right after cutting meat & $6.8 \pm 0.32$ & $7.0 \pm 0.12$ & $7.1 \pm 0.15$ \\
\hline $\mathrm{pH}$ thănthịtsau 45 phút & $5.5 \pm 0.21$ & $5.3 \pm 0.24$ & $5.2 \pm 0.26$ \\
\hline Cholesterol (mmol/L) blood & $1.65 \pm 1.23$ & $2.15 \pm 0.91$ & $3.11 \pm 1.89$ \\
\hline Triglycerid (mmol/L) blood & $2.3 \pm 1.34$ & $2.8 \pm 0.98$ & $2.6 \pm 1.12$ \\
\hline
\end{tabular}

(source: Thai Nguyen University of Agriculture and Forestry,Wild pigs project, Bui Thi Thom, 2013)

Table 7 shows: The color of tenderloin of wild boar in the experiment fluctuated the average value of color index Minilta L* (brightness) from $47.83 ; 47.95 ; 48.02$ and has a bright red color. The results were similar between the experimental groups, but the batch with a high percentage of protein tended to have higher color values, but the difference was not significant. Research by Ton et al. (2012) L* values are 43.08 - 46.88. Research by author Townsend et al. (1978) for European wild boar forest has a $L^{*}$ value of 37.72 lower than our results. Meanwhile, according to Warriss and Brown (1995) Minolta $L^{*}$ value indicates the ability to accept light color of meat and is usually in the range of 49-60.

In Vietnam, Ton and Thang (2009) showed that for three-breed hybrid pigs (DYL), the L* value is $47.21-49.54$, so this result is equivalent to the result. our research results. The results of measuring the $\mathrm{pH}$ of the loin meat immediately after slaughter and 45 minutes after surgery showed that the trend was significantly reduced between the time after 45 minutes, but between the experimental groups, the results were similar. Marcgiori and Felicio (2003) (Excerpt from Ton et al., 2012) stated that the pH of wild boar loin decreased more slowly than that of domesticated and interbred wild boar. The value decreased from 6.18 to 5.57 after 24 hours in wild boar and 6.09 to 5.46 in foreign pork loin. Research by Ton et al. (2012) showed that the $\mathrm{pH}$ of 45 minutes for Ban pigs and crossbred pigs (Ban x MC) is 6.13. Hao (2007) also studied in pigs L, Y and F1 (L x Y) that pH45 was 6.12 - 6.19 - 6.15, respectively.

The experiment also studied the concentration of Cholesterol and Triglyceride in the blood of experimental pigs and found that there was a large difference between the batches. Colesterol content tends to increase gradually with the percentage of protein in the diet decreasing from $2.65-2.15-3.11 \mathrm{~mol} / \mathrm{L}$. The content of Triglycerides increases when the percentage of fat in the experimental batches increases. (test batches 2 and 3). This we find, when the diet reduces the percentage of protein, the pigs have to accumulate more energy-rich food, and the pigs accumulate more fat. Therefore, the concentration of Colesterol and Triglyceride increased in the blood of experimental pigs.

\section{Discussion and Conclusion}

For the experiment with an energy level of 3000-2900 kcal $/ \mathrm{kg}$ of feed, with the corresponding protein level of $16-14 \%$, the growth rate increased to $4.31 \%(0.89 \mathrm{~kg} / \mathrm{head})$ and excellent growth. increase $5.59 \%$ (5.21 g/head/day); reduced feed consumption in which $4.71 \%$ concentrate and $5.97 \%$ green feed, and at the same time reduced feed cost by $4.74 \%$ compared to the experimental batch with energy level of $2900-2800 \mathrm{kcal} / \mathrm{kg}$ food at the same age. Evaluation of pork performance in Experiment 2 between the experiments, there was no significant difference between the ratio of jaw hook, lean meat, and sawn meat, and there was no statistical significance. It also does not affect the chemical composition of the meat.

Thus, for commercial wild boar farming, the diet has a protein level of 16-14\% and a metabolic energy level of 3000-2900 kcal/kg of feed in the diet for growth and fattening stages respectively is the 
most reasonable, both capable of growth of hybrid wild boar and economically viable in breeding conditions by semi-wild method in ecological conditions of Thai Nguyen.

Recommendations for value-chain approach

In recent years, esecially under covid 19 effects, the concept of cycled economy is important to maintain high rate of employment and hep the economic growth. Therefore, every stages in wild pigs and pork cycle from input to production and distribution to market need to be in a cycle and can be supported by big corporations. Huy (2015) also stated better management practices needed. Whereas Huy et al (2020) mentioned banks roles in business financing.

Banks also need to finance this value chain or wild pigs and pork cycle.

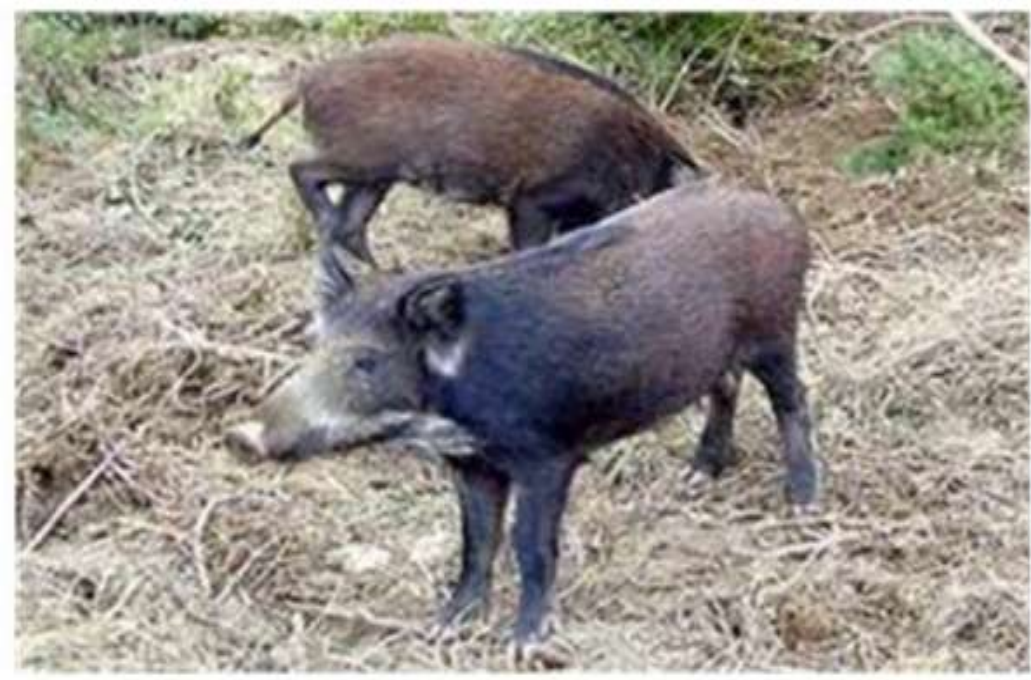

Limitation of research

Figure 2 - Wild pigs feeding in Thai Nguyen, Vietnam (source: internet)

Due to the limited study time, we have only studied a limited number of studies and have not arranged pairwise comparison plots of each protein reduction level with each corresponding metabolic energy level at the same time, so the results The study cannot comprehensively reflect the influence of crude protein on growth and other economic indicators.

It is recommended that when raising wild boar and crossbreeds, it is necessary to arrange more experiments with some other energy levels to evaluate more accurately. Tinh et al (2021) stated we need to enhance research to explore business aspects. And Huy (2021) confirmed roles of banks in sustainable development while Hac et al (2021) mentioned we need risk management in bank financing which also referred by Huy, (2021), though there are many macro factors affecting (Huy et al 2021). And banks show roles in financing to develop the industry (Huy et al 2021). Hang et al (2021) stated labor force is vital in these business. Then Huy, D.T.N. (2015) stated several management practices needed for doing business, this also mentioned by Huy \& Hien (2010).

\section{References}

1) Hac, L.D., Huy, D.T.N., Thach, N.N., Chuyen. B.M., Nhung, P.T.H., Thang, T.D., \& Anh, T.T. (2021). Enhancing risk management culture for sustainable growth of Asia commercial bank -ACB in Vietnam under mixed effects of macro factors, Entrepreneurship and Sustainability Issues, 8(3): 291-307.

2) Hang N.T., Huy D.T.N.. (2021). Better Risk Management of Banks and Sustainability-A Case Study in Vietnam, Revista geintec Inovacao E Tecnologias, 11(2)

3) Hang, N.T., Tinh, D.T., Huy, D.T.N., \& Nhung, P.T.H. (2021). Educating and training labor force Under Covid 19; Impacts to Meet Market Demand in Vietnam during Globalization and Integration Era, Journal for Educators, Teachers and Trainers, 12(1): 179-184. DOI: $10.47750 /$ jett.2021.12.01.023

4) Huy, D.T.N. (2015). The Critical Analysis of Limited South Asian Corporate Governance Standards After Financial Crisis, International Journal for Quality Research, 9(4): 741-764. 
Thom et al 2021/ J. Livestock Sci. 12: 303-311

5) Huy, D.T.N. (2012). Estimating Beta of Viet Nam listed construction companies groups during the crisis, Journal of Integration and Development, 15 (1), 57-71

6) Huy, D.T.N., \& Hien, D.T.N. (2010). The backbone of European corporate governance standards after financial crisis, corporate scandals and manipulation, Economic and business review, 12(4).

7) Huy, D.T.N., Loan, B.T., and Anh, P. T. (2020). Impact of selected factors on stock price: a case study of Vietcombank in Vietnam, Entrepreneurship and Sustainability Issues, 7(4): 27152730. https://doi.org/10.9770/jesi.2020.7.4(10)

8) Huy, D.T.N., Dat, P.M., và Anh, P.T. (2020). 'Building and econometric model of selected factors' impact on stock price: a case study', Journal of Security and Sustainability Issues, 9(M): 7793. https://doi.org/10.9770/jssi.2020.9.M(7)

9) Huy D.T.N., Nguyen T.H.. (2021). Factors that affect stock price and Beta CAPM of Vietnam Banks and Enhancing Management information system - Case of Asia Commercial Bank, Revista geintec-gestao Inovacao E Tecnologias, 11(2).

10) Huy D.T.N., Nhan V.K., Bich N.T.N., Hong N.T.P., Chung N.T., Huy P.Q. (2021). 'Impacts of Internal and External Macroeconomic Factors on Firm Stock Price in an Expansion Econometric modelA Case in Vietnam Real Estate Industry', Data Science for Financial Econometrics-Studies in Computational Intelligence, vol.898, Springer. http://doi-org-443.webvpn.fjmu.edu.cn/10.1007/978-3-030-48853-6_14

11) Huy, D.T.N., An, T.T.B., Anh, T.T.K., Nhung, P.T.H. (2021). Banking sustainability for economic growth and socio-economic development - case in Vietnam, Turkish Journal of Computer and Mathematics Education, 12(2), pp. 2544-2553

12) Huy, D.T.N. (2021). Banking sustainability for economic growth and socio-economic developmentcase in Vietnam, Turkish Journal of computer and mathematics education, 12(2): 2544-2553.

13) Huong, L.T.T., Huong, D.T., Huy, D.T.N., Thuy, N.T. (2021). Education for students to enhance research skills and meet demand from workplace-case in Vietnam, Elementary education online, 20(4).

14) Khwaja, A.I., Mian, A. (2005). Unchecked intermediaries:Price manipulation in an emerging stock market, Journal of Financial Economics 78, 243 - 241

15) Lan, L.T., Huy, D.T.N., Thom, B.T., Hang, N.T. (2021). Environment issues and feeding mechanism for wild pigs and wild pork processing during evfta in asian countries , International Journal of Ecosystems and Ecology Science (IJEES), 11(4): 685-692.

16) Phuc N.N., Coi N.Q., Hao P.X., Xa N.H., Sang L.V. and Binh N.T. (2010), Growth rate, yield and meat quality of Khua and F1 hybrid pigs (Wild boar x pig) Khua) in the mountainous region of Quang Binh, Journal of Animal Science and Technology - Institute of Livestock Production, No. 27, December 2010.

17) Simons, D., Francis, M., Bourlakis, M., Feame, A. (2008). Identifying the determinants of value in the U.K. red meat industry: A value chain analysis approach, Journal on Chain and Network Science: 3 (2): 109 - 121. https://doi.org/10.3920/JCNS2003.x034

18) Thom, B.T., Huy, D.T.N. (2021). Study on wild pork and pigs in thai nguyen, vietnam -and pork meat export criteria to europe, Revista geintec-gestao Inovacao E Tecnologias, 11(3): 51-65

19) Thom, B.T., Phung, T.V. (2013). Wild pigs project, Thai Nguyen University of Agriculture and Forestry, Vietnam

20) Thom, B.T, Huy, D.T.N., Phung, T.V. (2021). Improving Yield and Quality of Wild Pork and Pigs in Thai Nguyen, Vietnam - and Solutions to Enhance Competitiveness to Thailand and China, Alinteri Journal of agriculture science, 36(1): 746-752.

21) Thom B.T., Huy D.T.N., Hang N.T. 2021. Scientific study on feeding wild pigs and pork in Vietnam (Thai nguyen region). Journal of Livestock Science 12: 268-275.

22) Tinh D.T., Thuy N.T., Huy D.T.N. (2021). Doing Business Research and Teaching Methodology for Undergraduate, Postgraduate and Doctoral Students-Case in Various Markets Including Vietnam , Elementary education online, 20(1).

23) Trung N.V., Duyen T.T.B., Trung D.D., Duc N.V. and Tuan D.C. (2010). "Physical characteristics, growth and production capacity of the domestic Tap $\mathrm{Na}$ pig breed of Vietnam". www.vcn.vnn.vn/Main.aspx?MNU=1067\&Style=1\&ChiTiel=9995\&search=XX_SEARCH_XX (Accessed: September 30, 2010). 